\title{
Fabrication of Erbium and Ytterbium Co-Doped Tantalum-Oxide Thin Films Using Radio-Frequency Co-Sputtering
}

\author{
Kenta Miura*, Yuki Arai, Kazusa Kano, Osamu Hanaizumi \\ Graduate School of Science and Technology, Gunma University, Kiryu, Japan \\ Email: " mkenta@gunma-u.ac.jp
}

Received 15 February 2015; accepted 20 April 2015; published 21 April 2015

Copyright (C) 2015 by authors and Scientific Research Publishing Inc.

This work is licensed under the Creative Commons Attribution International License (CC BY). http://creativecommons.org/licenses/by/4.0/

(c) (i) Open Access

\begin{abstract}
An erbium and ytterbium co-doped tantalum-oxide $\left(\mathrm{Ta}_{2} \mathrm{O}_{5}: \mathrm{Er}, \mathrm{Yb}\right)$ thin film was fabricated using a simple co-sputtering method for the first time, and its photoluminescence (PL) spectrum was evaluated. Energy transfers between $\mathrm{Er}^{3+}$ and $\mathrm{Yb}^{3+}$ in the $\mathrm{Ta}_{2} \mathrm{O}_{5}: \mathrm{Er}$, $\mathrm{Yb}$ co-sputtered thin film were discussed by comparing between PL spectra of the $\mathrm{Ta}_{2} \mathrm{O}_{5}: \mathrm{Er}$, $\mathrm{Yb}$ film and $\mathrm{Ta}_{2} \mathrm{O}_{5}: \mathrm{Er}$ or $\mathrm{Ta}_{2} \mathrm{O}_{5}: \mathrm{Yb}$ films reported in our previous works. Such a $\mathrm{Ta}_{2} \mathrm{O}_{5}: \mathrm{Er}$, $\mathrm{Yb}$ co-sputtered film can be used as a high-refractive-index and light-emitting material of a multilayered photonic crystal that can be applied to a novel light-emitting device, and it will also be used as a multi-functional coating film having both anti-reflection and down-conversion effects for realizing a high-efficiency silicon solar cell.
\end{abstract}

\section{Keywords}

Tantalum Oxide, Erbium, Ytterbium, Co-Sputtering, Photoluminescence

\section{Introduction}

Many studies on rare-earth-doped tantalum (V) oxide $\left(\mathrm{Ta}_{2} \mathrm{O}_{5}\right)$ have been conducted because $\mathrm{Ta}_{2} \mathrm{O}_{5}$ is a potential host material for new phosphors due to its low phonon energy $\left(100-450 \mathrm{~cm}^{-1}\right)$ compared with other oxide materials such as $\mathrm{SiO}_{2}$ [1]. Visible photoluminescence (PL) from erbium-doped $\mathrm{Ta}_{2} \mathrm{O}_{5}\left(\mathrm{Ta}_{2} \mathrm{O}_{5}: \mathrm{Er}\right)$ produced by the sol-gel method [2] [3] and ion implantation [4] has been reported. Their PL spectra have main peaks at a wavelength of $550 \mathrm{~nm}$ due to the ${ }^{4} \mathrm{~S}_{3 / 2} \rightarrow{ }^{4} \mathrm{I}_{15 / 2}$ transition of $\mathrm{Er}^{3+}$, and at a wavelength of $670 \mathrm{~nm}$ due to the ${ }^{4} \mathrm{~F}_{9 / 2} \rightarrow{ }^{4} \mathrm{I}_{15 / 2}$ transition of $\mathrm{Er}^{3+}$. We previously demonstrated that $\mathrm{Ta}_{2} \mathrm{O}_{5}$ : $\mathrm{Er}$ thin films deposited using a simple co-sputtering method exhibited such PL peaks at wavelengths of 550 and $670 \mathrm{~nm}$ after annealing at $600^{\circ} \mathrm{C}$ to $1100^{\circ} \mathrm{C}$ [5] [6].

${ }^{*}$ Corresponding author.

How to cite this paper: Miura, K., Arai, Y., Kano, K. and Hanaizumi, O. (2015) Fabrication of Erbium and Ytterbium CoDoped Tantalum-Oxide Thin Films Using Radio-Frequency Co-Sputtering. Materials Sciences and Applications, 6, $343-347$. http://dx.doi.org/10.4236/msa.2015.65039 
Recently, we also fabricated ytterbium-doped $\mathrm{Ta}_{2} \mathrm{O}_{5}\left(\mathrm{Ta}_{2} \mathrm{O}_{5}: \mathrm{Yb}\right)$ thin films using the same co-sputtering method in order to expand the useful wavelength range of our rare-earth-doped and light-emitting $\mathrm{Ta}_{2} \mathrm{O}_{5}$ co-sputtered films [7]. We observed PL spectra having sharp peaks at a wavelength of $980 \mathrm{~nm}$ from the $\mathrm{Ta}_{2} \mathrm{O}_{5}: \mathrm{Yb}$ thin films after annealing at $700^{\circ} \mathrm{C}$ to $1000^{\circ} \mathrm{C}$ [7]. The 980-nm peaks seemed to be the result of the ${ }^{2} \mathrm{~F}_{5 / 2} \rightarrow{ }^{2} \mathrm{~F}_{7 / 2}$ transition of $\mathrm{Yb}^{3+}[7]$.

Furthermore, in our recent works, we demonstrated Tm and Ce co-doped $\mathrm{Ta}_{2} \mathrm{O}_{5}\left(\mathrm{Ta}_{2} \mathrm{O}_{5}: \mathrm{Tm}, \mathrm{Ce}\right)$ [8], Er and Ce co-doped $\mathrm{Ta}_{2} \mathrm{O}_{5}\left(\mathrm{Ta}_{2} \mathrm{O}_{5}: \mathrm{Er}, \mathrm{Ce}\right)$ [9], and Er, Eu, and Ce co-doped $\mathrm{Ta}_{2} \mathrm{O}_{5}\left(\mathrm{Ta}_{2} \mathrm{O}_{5}: \mathrm{Er}, \mathrm{Eu}, \mathrm{Ce}\right)$ [10] thin films prepared using the co-sputtering method. In this work, we fabricated an $\mathrm{Er}$ and $\mathrm{Yb}$ co-doped $\mathrm{Ta}_{2} \mathrm{O}_{5}\left(\mathrm{Ta}_{2} \mathrm{O}_{5}: \mathrm{Er}_{\text {, }}\right.$ $\mathrm{Yb}$ ) thin film using radio-frequency (RF) magnetron co-sputtering of $\mathrm{Ta}_{2} \mathrm{O}_{5}, \mathrm{Er}_{2} \mathrm{O}_{3}$, and $\mathrm{Yb}_{2} \mathrm{O}_{3}$ for the first time, and evaluated its PL property.

\section{Experimental}

A Ta $\mathrm{O}_{5}$ :Er, Yb thin film was prepared using our co-sputtering method reported in [5]-[13]. A $\mathrm{Ta}_{2} \mathrm{O}_{5}$ disc (99.99\% purity, diameter $100 \mathrm{~mm}$ ), two $\mathrm{Er}_{2} \mathrm{O}_{3}$ pellets (99.9\% purity, diameter $21 \mathrm{~mm}$ ), and two $\mathrm{Yb}_{2} \mathrm{O}_{3}$ pellets $(99.9 \%$ purity, diameter $21 \mathrm{~mm}$ ) were used as co-sputtering targets. The $\mathrm{Er}_{2} \mathrm{O}_{3}$ and $\mathrm{Yb}_{2} \mathrm{O}_{3}$ pellets were placed on the $\mathrm{Ta}_{2} \mathrm{O}_{5}$ disc as shown in Figure 1. The film was deposited using a RF magnetron sputtering system (ULVAC, SH-350-SE). The flow rate of Ar gas introduced into the vacuum chamber was $10 \mathrm{sccm}$, and the RF power supplied to the targets was $200 \mathrm{~W}$. A fused-silica plate (1 mm thick) was used as a substrate, and it was not heated during co-sputtering. We subsequently annealed the film in ambient air at $900^{\circ} \mathrm{C}$ for 20 min using an electric furnace (Denken, KDF S-70). The PL spectrum of the $\mathrm{Ta}_{2} \mathrm{O}_{5}: \mathrm{Er}$, Yb film was measured using a dual-grating monochromator (Roper Scientific, SpectraPro 2150i) and a CCD detector (Roper Scientific, Pixis:100B, electrically cooled to $-80^{\circ} \mathrm{C}$ ) under excitation with a He-Cd laser (Kimmon, IK3251R-F, wavelength $\lambda=325 \mathrm{~nm}$ ).

\section{Results and Discussion}

Figure 2 presents PL spectra of $\mathrm{Ta}_{2} \mathrm{O}_{5}: \mathrm{Er}, \mathrm{Yb}$ (red line) and $\mathrm{Ta}_{2} \mathrm{O}_{5}: \mathrm{Er}$ (without Yb, black line) [5] [6] co-sputtered thin films. We observed typical PL peaks around wavelengths of 550, 670, 850, and $980 \mathrm{~nm}$ from both the films. The 550-, 670-, and 850-nm peaks seem to be the results of the ${ }^{4} \mathrm{~S}_{3 / 2} \rightarrow{ }^{4} \mathrm{I}_{15 / 2},{ }^{4} \mathrm{~F}_{9 / 2} \rightarrow{ }^{4} \mathrm{I}_{15 / 2}$, and ${ }^{4} \mathrm{I}_{9 / 2} \rightarrow{ }^{4} \mathrm{I}_{15 / 2}$ transitions of $\mathrm{Er}^{3+}$, respectively [5] [14] [15]. The 980-nm peaks seem to be the results of the ${ }^{4} \mathrm{I}_{11 / 2} \rightarrow{ }^{4} \mathrm{I}_{15 / 2}$ transition of $\mathrm{Er}^{3+}$ or the ${ }^{2} \mathrm{~F}_{5 / 2} \rightarrow{ }^{2} \mathrm{~F}_{7 / 2}$ transition of $\mathrm{Yb}^{3+}$ [7] [14]-[16]. From Figure 2, we can find that the 550-, 670-, and 850 -nm peaks from the $\mathrm{Ta}_{2} \mathrm{O}_{5}$ :Er film decreased by $\mathrm{Yb}$ doping. In contrast, the intensity of the 980-nm peak from the $\mathrm{Ta}_{2} \mathrm{O}_{5}: \mathrm{Er}, \mathrm{Yb}$ film was stronger than that from the $\mathrm{Ta}_{2} \mathrm{O}_{5}$ : $\mathrm{Er}$ film. This seems to be because of overlapping between the above-mentioned ${ }^{4} \mathrm{I}_{11 / 2} \rightarrow{ }^{4} \mathrm{I}_{15 / 2}$ transition of $\mathrm{Er}^{3+}$ and the ${ }^{2} \mathrm{~F}_{5 / 2} \rightarrow{ }^{2} \mathrm{~F}_{7 / 2}$ transition of $\mathrm{Yb}^{3+}$, and energy transfers from $\mathrm{Er}^{3+}$ to $\mathrm{Yb}^{3+}$ reported in [14]. Figure 3 illustrates energy level diagrams of $\mathrm{Er}^{3+}$ and $\mathrm{Yb}^{3+}$ [14] [15]. The energies of ${ }^{4} \mathrm{~S}_{3 / 2}$ (the origin of the $550-\mathrm{nm}$ peak), ${ }^{4} \mathrm{~F}_{9 / 2}$ (the origin of the $670-\mathrm{nm}$ peak), and ${ }^{4} \mathrm{I}_{9 / 2}$ (the origin of the 850-nm peak) states of $\mathrm{Er}^{3+}$ seem to transfer through the ${ }^{4} \mathrm{I}_{11 / 2}$ state of $\mathrm{Er}^{3+}$ to the ${ }^{2} \mathrm{~F}_{5 / 2}$ state of $\mathrm{Yb}^{3+}$ as presented in Figure 3.

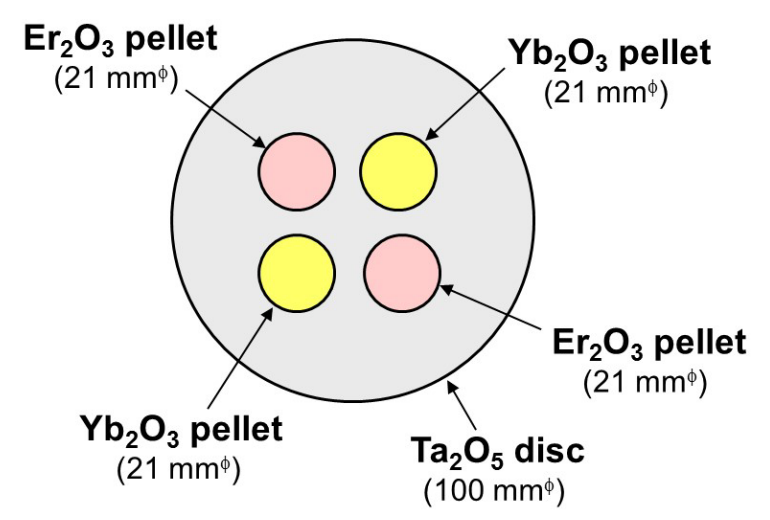

Figure 1. Schematic diagram of the sputtering target for cosputtering of $\mathrm{Er}_{2} \mathrm{O}_{3}, \mathrm{Yb}_{2} \mathrm{O}_{3}$, and $\mathrm{Ta}_{2} \mathrm{O}_{5}$ used in this work. 
Figure 4 presents PL spectra of the same $\mathrm{Ta}_{2} \mathrm{O}_{5}: \mathrm{Er}, \mathrm{Yb}$ film (red line) and a $\mathrm{Ta}_{2} \mathrm{O}_{5}: \mathrm{Yb}$ film (without Er, green line) reported in [7]. The 980-nm peak from the $\mathrm{Ta}_{2} \mathrm{O}_{5}: \mathrm{Yb}$ film is much stronger than that from the $\mathrm{Ta}_{2} \mathrm{O}_{5}: \mathrm{Er}, \mathrm{Yb}$ film. This seems to be because the opposite energy transfer from $\mathrm{Yb}^{3+}$ to $\mathrm{Er}^{3+}$ occurred in the $\mathrm{Ta}_{2} \mathrm{O}_{5}: \mathrm{Er}$, $\mathrm{Yb}$ film. The energy of the ${ }^{2} \mathrm{~F}_{5 / 2}$ state of $\mathrm{Yb}^{3+}$ partially transfer to the ${ }^{4} \mathrm{I}_{11 / 2}$ state of $\mathrm{Er}^{3+}$ at first, and subsequently relax to the ${ }^{4} \mathrm{I}_{13 / 2}$ state as presented in Figure 3. Finally light emission around a wavelength of $1550 \mathrm{~nm}$ due to the ${ }^{4} \mathrm{I}_{13 / 2} \rightarrow \mathrm{I}_{15 / 2}$ transition of $\mathrm{Er}^{3+}$ seems to occur [14]. The 1550-nm emission may cause the decrease of the 980nm-peak intensity. Unfortunately, our detector did not detect the light emission in the wavelength range. We will try to evaluate the light-emission properties of our $\mathrm{Ta}_{2} \mathrm{O}_{5}: \mathrm{Er}$, Yb films in the near-infrared range in order to make the mechanism of the energy transfer between $\mathrm{Er}^{3+}$ and $\mathrm{Yb}^{3+}$ clearer.

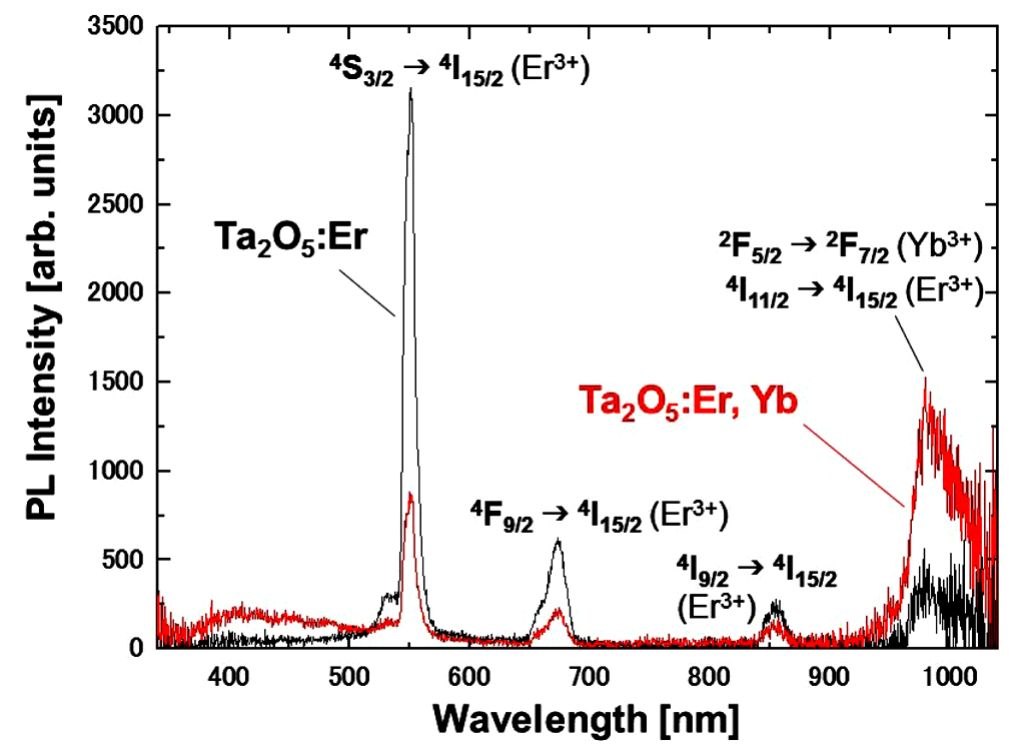

Figure 2. PL spectra of $\mathrm{Ta}_{2} \mathrm{O}_{5}: \mathrm{Er}, \mathrm{Yb}$ and $\mathrm{Ta}_{2} \mathrm{O}_{5}: \mathrm{Er}$ [5] [6] co-sputtered thin films.

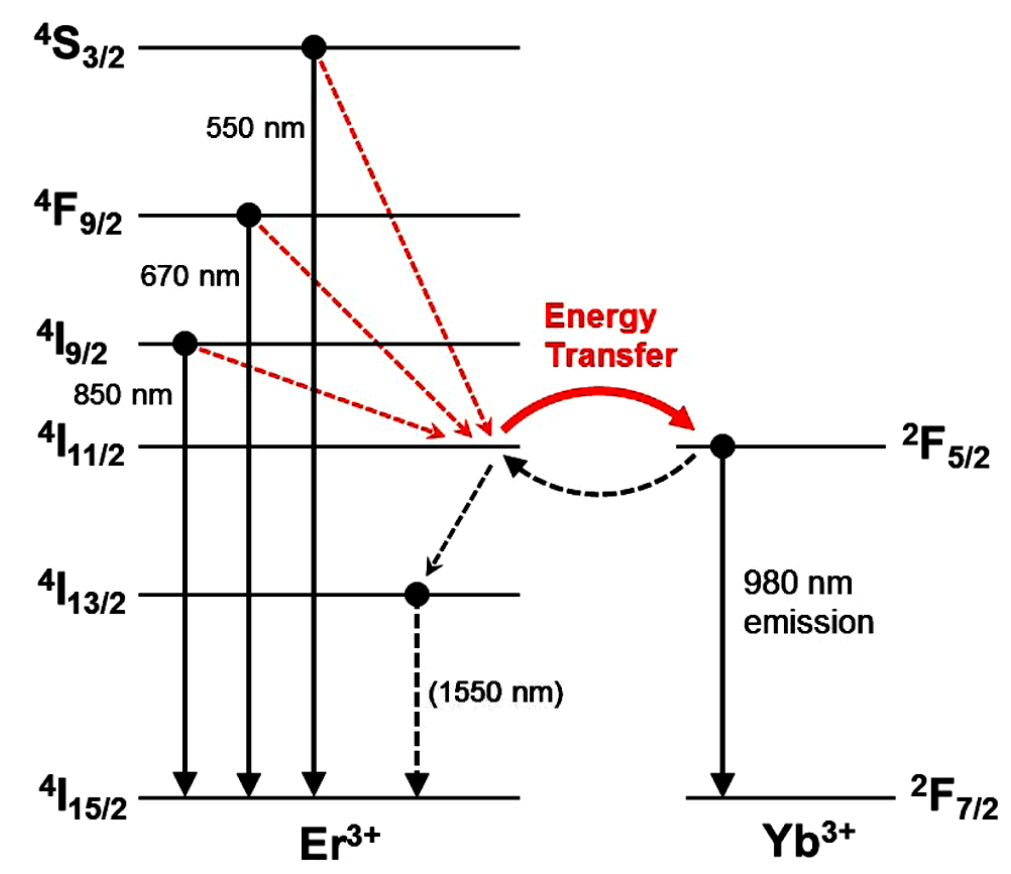

Figure 3. Energy level diagrams of $\mathrm{Er}^{3+}$ and $\mathrm{Yb}^{3+}$ [14] [15]. 


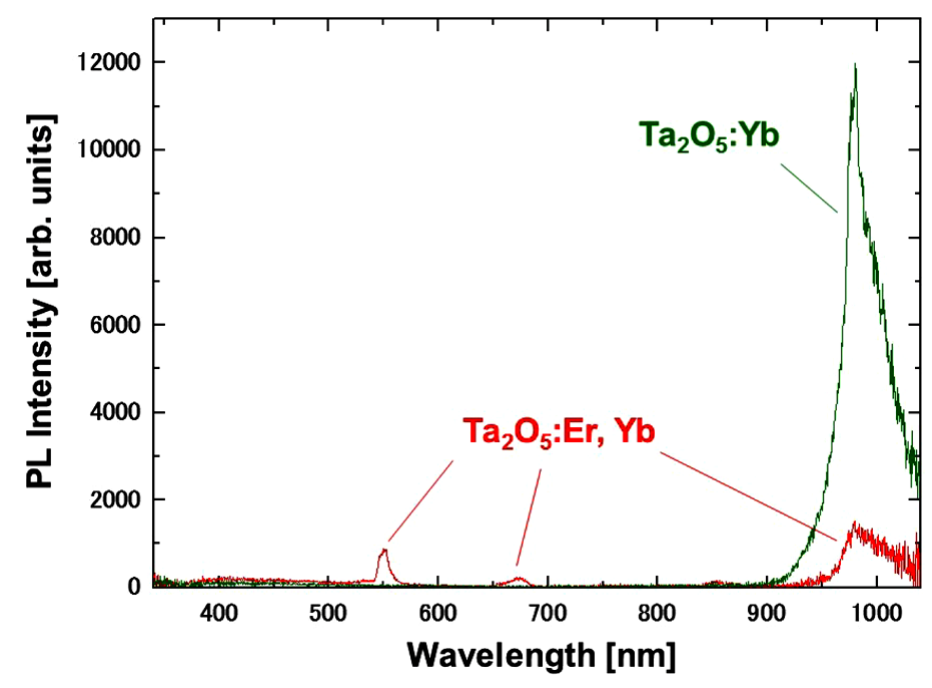

Figure 4. PL spectra of $\mathrm{Ta}_{2} \mathrm{O}_{5}: \mathrm{Er}, \mathrm{Yb}$ and $\mathrm{Ta}_{2} \mathrm{O}_{5}: \mathrm{Yb}$ [7] co-sputtered thin films.

Such a $\mathrm{Ta}_{2} \mathrm{O}_{5}: \mathrm{Er}, \mathrm{Yb}$ co-sputtered thin film can be used as a high-refractive-index and light-emitting material of a multilayered photonic crystal that can be applied to a novel light-emitting device [17], and it will also be used as a multi-functional coating film having both anti-reflection [18] and down-conversion [14]-[16] effects for realizing a high-efficiency silicon solar cell.

\section{Summary}

A $\mathrm{Ta}_{2} \mathrm{O}_{5}$ : $\mathrm{Er}$, $\mathrm{Yb}$ thin film was fabricated using our simple co-sputtering method for the first time, and its PL spectrum was evaluated. Energy transfers between $\mathrm{Er}^{3+}$ and $\mathrm{Yb}^{3+}$ in our $\mathrm{Ta}_{2} \mathrm{O}_{5}: \mathrm{Er}, \mathrm{Yb}$ co-sputtered film were discussed by comparing between PL spectra of the film and our $\mathrm{Ta}_{2} \mathrm{O}_{5}: \mathrm{Er}$ or $\mathrm{Ta}_{2} \mathrm{O}_{5}: \mathrm{Yb}$ films. Such a $\mathrm{Ta}_{2} \mathrm{O}_{5}: \mathrm{Er}$, $\mathrm{Yb}$ co-sputtered thin film can be used as a high-refractive-index and light-emitting material of a multilayered photonic crystal that can be applied to a novel light-emitting device, and it will also be used as a multi-functional coating film having both anti-reflection and down-conversion effects for realizing a high-efficiency silicon solar cell.

\section{Acknowledgements}

Part of this work was supported by the "Element Innovation” Project by Ministry of Education, Culture, Sports, Science and Technology in Japan; and JSPS KAKENHI Grant Number 26390073. Part of this work was conducted at the Human Resources Cultivation Center (HRCC), Gunma University, Japan.

\section{References}

[1] Sanada, T., Wakai, Y., Nakashita, H., Matsumoto, T., Yogi, C., Ikeda, S., Wada, N. and Kojima, K. (2010) Preparation of $\mathrm{Eu}^{3+}$-Doped $\mathrm{Ta}_{2} \mathrm{O}_{5}$ Phosphor Particles by Sol-Gel Method. Optical Materials, 33, 164-169. http://dx.doi.org/10.1016/j.optmat.2010.08.018

[2] Kojima, K., Yoshida, S., Shiraishi, H. and Maegawa, A. (1995) Green Upconversion Fluorescence in Er ${ }^{3+}-$ Doped $^{-}$ $\mathrm{Ta}_{2} \mathrm{O}_{5}$ Heated Gel. Applied Physics Letters, 67, 3423-3425. http://dx.doi.org/10.1063/1.115267

[3] Wada, N., Kubo, M., Maeda, N., Akira, M. and Kojima, K. (2004) Fluorescence Property and Dissolution Site of Er ${ }^{3+}$ in $\mathrm{Ta}_{2} \mathrm{O}_{5}$ Film Prepared by Sol-Gel Method and Dip-Coating Technique. Journal of Materials Research, 19, 667-675. http://dx.doi.org/10.1557/jmr.2004.19.2.667

[4] Rigneault, H., Flory, F., Monneret, S., Robert, S. and Roux, L. (1996) Fluorescence of $\mathrm{Ta}_{2} \mathrm{O}_{5}$ Thin Films Doped by Kilo-Electron-Volt Er Implantation: Application to Microcavities. Applied Optics, 35, 5005-5012. http://dx.doi.org/10.1364/AO.35.005005

[5] Singh, M.K., Fusegi, G., Kano, K., Bange, J.P., Miura, K. and Hanaizumi, O. (2009) Intense Photoluminescence from Erbium-Doped Tantalum Oxide Thin Films Deposited by Sputtering. IEICE Electronics Express, 6, 1676-1682. 
http://dx.doi.org/10.1587/elex.6.1676

[6] Singh, M.K., Miura, K., Fusegi, G., Kano, K. and Hanaizumi, O. (2013) Visible-Light Emission Properties of ErbiumDoped Tantalum-Oxide Films Produced by Co-Sputtering. Key Engineering Materials, 534, 154-157. http://dx.doi.org/10.4028/www.scientific.net/KEM.534.154

[7] Miura, K., Kano, K., Arai, Y. and Hanaizumi, O. (2015) Preparation of Light-Emitting Ytterbium-Doped TantalumOxide Thin Films Using a Simple Co-Sputtering Method. Materials Sciences and Applications, 6, 209-213. http://dx.doi.org/10.4236/msa.2015.62024

[8] Miura, K., Osawa, T., Yokota, Y., Suzuki, T. and Hanaizumi, O. (2015) Photoluminescence Properties of Thulium and Cerium Co-Doped Tantalum-Oxide Films Prepared by Radio-Frequency Co-Sputtering. Materials Sciences and Applications, 6, 263-268. http://dx.doi.org/10.4236/msa.2015.64031

[9] Miura, K., Osawa, T., Suzuki, T., Yokota, Y. and Hanaizumi, O. (2015) Fabrication and Evaluation of Green-Light Emitting $\mathrm{Ta}_{2} \mathrm{O}_{5}$ :Er, Ce Co-Sputtered Thin Films. Results in Physics, 5, 78-79. http://dx.doi.org/10.1016/j.rinp.2015.02.002

[10] Miura, K., Osawa, T., Suzuki, T., Yokota, Y. and Hanaizumi, O. (2015) Yellow Light Emission from Ta $2 \mathrm{O}_{5}: \mathrm{Er}_{\text {, Eu, Ce }}$ Thin Films Deposited Using a Simple Co-Sputtering Method. Results in Physics, 5, 26-27. http://dx.doi.org/10.1016/j.rinp.2014.11.003

[11] Miura, K., Arai, Y., Osawa, T. and Hanaizumi, O. (2012) Light-Emission Properties of Europium-Doped TantalumOxide Thin Films Deposited by Radio-Frequency Magnetron Sputtering. Journal of Light and Visual Environment, 36, 64-67. http://dx.doi.org/10.2150/jlve.36.64

[12] Miura, K., Osawa, T., Yokota, Y., Suzuki, T. and Hanaizumi, O. (2014) Fabrication of Tm-Doped Ta $\mathrm{O}_{5} \mathrm{Thin}_{\text {Films }}$ Using a Co-Sputtering Method. Results in Physics, 4, 148-149. http://dx.doi.org/10.1016/j.rinp.2014.08.011

[13] Miura, K., Osawa, T., Yokota, Y. and Hanaizumi, O. (2014) Fabrication and Evaluation of $\mathrm{Ta}_{2} \mathrm{O}_{5}: \mathrm{Y}_{2} \mathrm{O}_{3}$ Co-Sputtered Thin Films. Results in Physics, 4, 185-186. http://dx.doi.org/10.1016/j.rinp.2014.09.004

[14] Rodriguez, V.D., Tikhomirov, V.K., Mendez-Ramos, J., Yanes, A.C. and Moshchalkov, V.V. (2010) Towards Broad Range and Highly Efficient Down-Conversion of Solar Spectrum by $\mathrm{Er}^{3+}-\mathrm{Yb}^{3+}$ Co-Doped Nano-Structured GlassCeramics. Solar Energy Materials and Solar Cells, 94, 1612-1617. http://dx.doi.org/10.1016/j.solmat.2010.04.081

[15] Aarts, L., van der Ende, B.M. and Meijerink, A. (2009) Downconversion for Solar Cells in NaYF 4 :Er, Yb. Journal of Applied Physics, 106, Article ID: 023522. http://dx.doi.org/10.1063/1.3177257

[16] Ueda, J. and Tanabe, S. (2011) Broadband near Ultra Violet Sensitization of $1 \mu \mathrm{m}$ Luminescence in $\mathrm{Yb}^{3+}$-Doped CeO Crystal. Journal of Applied Physics, 110, Article ID: 073104. http://dx.doi.org/10.1063/1.3642984

[17] Hanaizumi, O., Miura, K., Saito, M., Sato, T., Kawakami, S., Kuramochi, E. and Oku, S. (2000) Frontiers Related with Automatic Shaping of Photonic Crystals. IEICE Transactions on Electronics, E83-C, 912-919.

[18] Cid, M., Stem, N., Brunetti, C., Beloto, A.F. and Ramos, C.A.S. (1998) Improvements in Anti-Reflection Coatings for High-Efficiency Silicon Solar Cells. Surface and Coatings Technology, 106, 117-120. http://dx.doi.org/10.1016/S0257-8972(98)00499-X 